\title{
Impact of trainer and judges in the mare performance test of Warmblood Horses
}

\author{
Dedicated to Prof. Dr. sc. Lothar Panicke on the occasion of his $65^{\text {th }}$ birthday
}

\begin{abstract}
Data of the mare performance test of the Mecklenburger Warmblood Horses were used to estimate genetic and phenotypic (co-)variance components. The data set included the records of 1628 mares tested on station in the years 1993 to 2004. The pedigree contained information of 9560 horses. The investigated traits were trot, canter, walk, manner, ability and ride ability, according to trainer, judges and foreign riders. The estimated heritability coefficients, genetic and phenotypic correlations are in the range of the results report by other authors. The ride ability earns an exception position because a very low heritability was found. A comparison of the heritability coefficients between the trainers' scores and judges' scores makes very evident that the trainers are more able to evaluate the breeding value of the mare. This can probably be caused by the longer observation time of trainers during the stay of the mare on station lasting 14 days in comparison to the judges having only approximately 10 minutes. The current weights of trainers' scores and of judges' scores with 0.5 to 0.5 to generate the total score is not optimal. A stronger emphasis on the scores of the trainers promises an increasing breeding success of approximately 5 to 7 percent.
\end{abstract}

Key Words: mare performance test, station, parameter estimation, trainer, judges

\section{Zusammenfassung}

Titel der Arbeit: Die Wirkung von Trainer und Richtern in der Stutenleistungsprüfung des Warmblutes

Daten der Stutenleistungsprüfung des Mecklenburger Warmbluts wurden zur Schätzung genetischer und phänotypischer Varianz-Kovarianz Komponenten verwendet. Das Datenmaterial umfasste die Ergebnisse von 1628 auf Station geprüfter Stuten der Jahre 1993 bis 2004. Das Pedigree enthielt Angaben über 9560 Pferde. Die untersuchten Merkmale waren Trab, Galopp, Schritt, Manier, Vermögen und Rittigkeit, separiert nach Trainer, Richter und Fremdreiter. Die geschätzten Heritabilitätskoeffizienten, genetische und phänotypische Korrelationen liegen im Bereich der Resultate, die von anderen Autoren berichtet werden. Eine Ausnahmestellung nimmt das Merkmal Rittigkeit ein, für das sehr niedrige Heritabilitäten gefunden wurden. Ein Vergleich der Heritabilitätskoeffizienten zwischen den Noten der Trainer und Richter macht sehr deutlich, dass es den Trainern besser gelingt die Veranlagungen der Stuten zu erkennen. Das kann wahrscheinlich darauf zurückgeführt werden, dass die Trainer während des 14-tägigen Stationsaufenthaltes eine Stute länger beobachten können als die Richter, denen dafür nur etwa 10 Minuten zur Verfügung stehen. Die gegenwärtige Gewichtung der Noten der Trainer und Richter mit 0.5 zu 0.5 zur Gesamtnote eines Merkmals ist nicht optimal. Eine stärkere Betonung der Noten der Trainer verspricht einen züchterischen Gewinn von etwa 5 bis $7 \%$.

Schlüsselwörter: Stutenleistungsprüfung, Station, Parameterschätzung, Trainer, Richter

\section{Introduction}

The genetic evaluation in sport horses include the non genetic factors and among other the factor rider. It contrast to body traits, this test factor just like the investigation of the genetic connection in the mare performance test in the context with the test into stations till now examined inadequately (DIETL et al.; 2004; KOENEN, 2002; 
BOESCH et al., 2000; KÜHL et al., 1994). The mare performance test on stations evaluates ride ability, gaits under saddle and free jumping ability. In the flat work, the mare must show ability to lengthen in the trot, freedom and regularity of gaits, impulsion, balance and willingness. For free jumping, the mare is scored on technique, scope and willingness. All mares have to complete a pre-evaluation before they are trained on the station over 14 days. In a final test, the mares are evaluated by a trainer and by two recognized experts, i.e. FN-approved official judges. The average of the judge's scores is summarized in the proportion 1:1 with the score of the trainer. For ride ability, the scores of trainer and of a foreign rider are averaged. The current practice is to take these averages as the data basis for breeding value estimation of stallions and mares (BUGISLAUS et al., 2004; ROEHE et al., 2001; SCHWARK et al., 1992). The question arise whether these pre-fixed proportions of weights for scores from trainers, judges and foreign riders are optimal in the estimation of breeding values. Therefore, the aim of this work is to estimate genetic parameters separately for scores from trainers, judges and foreign riders and to analyse the results to give more insights into the impact of scores from trainers, judges and foreign riders on genetic evaluation.

\section{Materials and methods}

Data:

In the period from 1993 until 2004 observations on 1628 mares were collected. All animals were registered by the Association of Horse Breeders of MecklenburgWestern Pomerania. The recorded traits in combination with information about the place and date of test, pedigree, breed and date of birth were scores for trot, canter, walk, ride ability, manner and ability, recorded separately for trainers, averaged judges scores and in the case of ride ability also for foreign riders (Table 1). Some of these traits can be assigned to groups named gaits (trot, canter, walk) and free jumping (manner, ability). The ride ability characterizes a special quality of the horse. Therefore, it cannot be grouped in one of the named groups. The pedigree contained all recorded animals and, in most cases, four generations of ancestors. Total pedigree size was 9560 horses. The composition of judging team, trainer and foreign rider changed with the event. The scores were on a 1 to 10 scale, where 1 is the lowest and 10 is the highest value, with an increment of 0.5 . The average of the judge's scores was summarized in the proportion 1:1 with the score of the trainer in order to get total scores. For the trait ride ability the scores of trainer and of a foreign rider were averaged to the total score.

Data analysis:

For estimation of variance components, a multi-trait animal model was fitted given for a single trait as follows:

$$
\mathrm{y}=\mathrm{X} \beta+\mathrm{Zu}+\varepsilon,
$$

where $y$ is the vector of observed score of each trait; $\beta$ is the vector of the fixed effects year, month and place of test, age group and breed; $u$ is the vector of the random additive genetic effects and $\varepsilon$ is the vector of random residual effects. $\mathrm{X}$ and $\mathrm{Z}$ are the corresponding design matrixes. The estimation was done with the REML program package VCE 4.2.5 (GROENEVELD, 1998). All traits could not be included in one 
analysis so the data was analyzed with subsets of traits. The resulting variance covariance matrixes were not positive semi-definite and therefore a bending procedure was implemented. The total scores of the traits are the arithmetic means of the scores of trainer and the averaged scores of the judges with exception of ride ability, which is the average of trainer and foreign rider. The average of trot, canter and walk emerges the basic gaits. Free jumping is the mean value of manner and ability. All total scores are linear functions of original scores. Consequently, their variances and co-variances could be calculated on the basis of the rules to calculate variances and co-variances of linear functions. All fixed effects of the model were estimated with the program PEST (GROENEVELD and KOVAC, 1990) and the sum of all contrasts of these effects were tested for significance by the $\chi^{2}$ test implemented in the PEST package.

\section{Results}

Sample sizes, mean values, standard deviations, variation coefficients, minima and maxima are given in Table 1.

Table 1

Sample sizes, means, standard deviations, coefficients of variation and extreme values by traits of mare performance test (Stichprobengrößen, Mittelwerte, Standardabweichungen, Variationskoeffizienten und Extremwerte bei Merkmalen der Stutenleistungsprüfung )

\begin{tabular}{|c|c|c|c|c|c|c|c|}
\hline & Trait & $\mathrm{n}$ & Mean & $\begin{array}{l}\text { Standard } \\
\text { deviation }\end{array}$ & $\begin{array}{l}\text { Coefficient } \\
\text { of variation }\end{array}$ & Min & Max \\
\hline \multirow[t]{2}{*}{ Trot } & Trainer & 1628 & 7.10 & 0.72 & $10 \%$ & 4.0 & 9.5 \\
\hline & Judges & 1625 & 6.53 & 0.74 & $11 \%$ & 4.0 & 10 \\
\hline \multirow[t]{2}{*}{ Canter } & Trainer & 1628 & 7.20 & 0.66 & $9 \%$ & 4.0 & 9.5 \\
\hline & Judges & 1625 & 6.76 & 0.70 & $10 \%$ & 4.5 & 9.0 \\
\hline \multirow[t]{2}{*}{ Walk } & Trainer & 1628 & 7.15 & 0.77 & $11 \%$ & 4.0 & 10 \\
\hline & Judges & 1625 & 6.74 & 0.81 & $12 \%$ & 3.5 & 9.0 \\
\hline \multirow[t]{2}{*}{ Manner } & Trainer & 1628 & 7.23 & 0.73 & $10 \%$ & 4.5 & 9.5 \\
\hline & Judges & 1628 & 6.94 & 0.93 & $13 \%$ & 4.0 & 10 \\
\hline \multirow[t]{2}{*}{ Ability } & Trainer & 1628 & 7.51 & 0.85 & $11 \%$ & 5.0 & 10 \\
\hline & Judges & 1628 & 7.21 & 0.93 & $13 \%$ & 4.0 & 10 \\
\hline \multirow[t]{3}{*}{ Ride ability } & Trainer & 1628 & 7.10 & 0.70 & $10 \%$ & 3.5 & 9.5 \\
\hline & Judges & 1453 & 6.82 & 0.60 & $9 \%$ & 4.5 & 9.0 \\
\hline & Foreign rider & 1625 & 6.83 & 0.94 & $14 \%$ & 3.0 & 10 \\
\hline
\end{tabular}
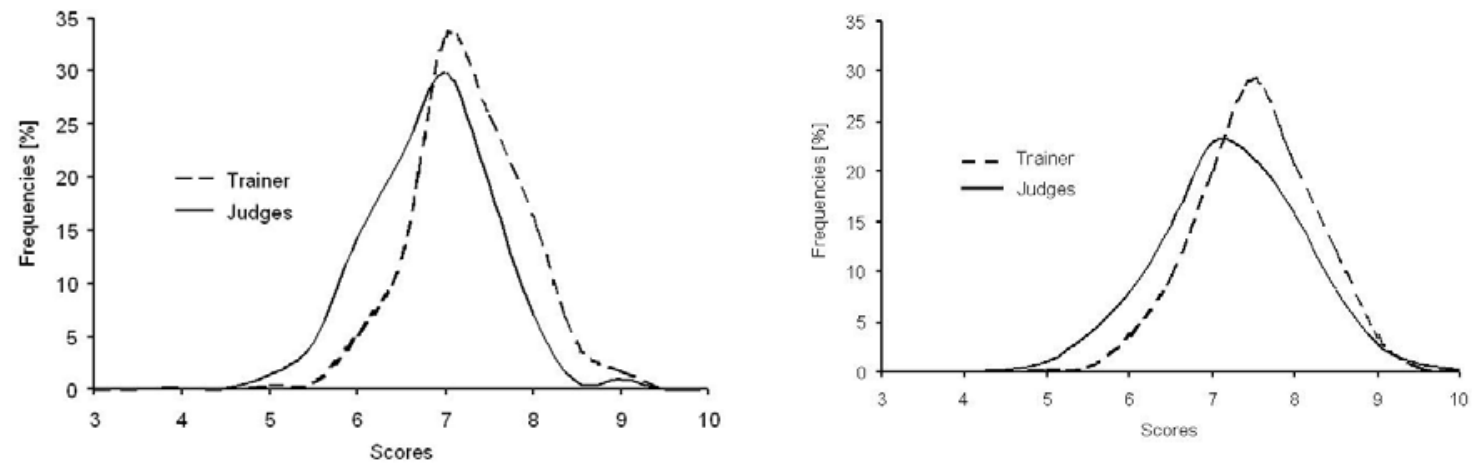

Fig. 1: Distributions of the trainer's scores and judges' scores in the trait canter (left) and free jumping (right). (Verteilungen der Noten von Trainern und Richtern im Merkmal Galopp (links) und Freispringen (rechts).)

The mean values of the trainer's scores are always larger than the judges' scores. They, however, show a lower variability, with exception of the trait ride ability. The 
differences between maximum and minimum score values indicate that the possible range of the evaluation scale has not been fully exploited by both the judges and the trainers and that could be a resource for more exactness. The shapes of the distributions of trainer's scores and judges' scores are similarly and both are well approximated by a normal distribution. For instance, see the Figure 1 . The effects of the years were significant in all examined traits. Also the effects of the place were significant with exception of the trait walk scored by the judges. The evaluations by the trainers showed significant effects caused by the months, with exception of the trait ride ability. That could be not observed for the judges' scores. The same tendency was found for the effect of different age groups. The corresponding effects were more frequently significant for the trainers' scores compared to those of the judges. The effects of breeds were not significant with exception of the traits trot (trainer) and ride ability (judges). Table 2 presents the heritabilities and the genetic and phenotypic correlation coefficients for total scores. These parameters are sufficiently exact for comparison with results of other studies, because their standard errors ranged in the region of 0.03 to 0.05 and 0.01 to 0.12 for heritabilities and genetic correlation coefficients, respectively.

Table 2

Heritabilities (bold), phenotypic correlation coefficients (above diagonal) and genetic correlation coefficients (below diagonal) of total scores. (Heritabilitätskoeffizienten (fett), phänotypische Korrelationskoeffizienten (oberhalb Diagonale) und genetische Korrelationskoeffizienten (unterhalb Diagonale) der Gesamtnoten.)

\begin{tabular}{lcccccccccc}
\hline Trait & & $(1)$ & $(2)$ & $(3)$ & $(4)$ & $(5)$ & $(6)$ & $(7)$ & $(8)$ \\
\hline Trot & $(1)$ & $\mathbf{0 . 3 4}$ & 0.67 & 0.43 & 0.85 & 0.20 & 0.24 & 0.24 & 0.47 \\
Canter & $(2)$ & 0.72 & $\mathbf{0 . 4 0}$ & 0.42 & 0.84 & 0.28 & 0.33 & 0.33 & 0.55 \\
Walk & $(3)$ & 0.53 & 0.49 & $\mathbf{0 . 3 2}$ & 0.77 & 0.15 & 0.17 & 0.17 & 0.38 \\
Basic gaits & $(4)$ & 0.88 & 0.87 & 0.80 & $\mathbf{0 . 3 8}$ & 0.26 & 0.30 & 0.30 & 0.57 \\
Manner & $(5)$ & 0.30 & 0.42 & 0.01 & 0.28 & $\mathbf{0 . 4 4}$ & 0.74 & 0.93 & 0.38 \\
Ability & $(6)$ & 0.29 & 0.37 & 0.04 & 0.27 & 0.84 & $\mathbf{0 . 5 8}$ & 0.94 & 0.37 \\
Free jumping & $(7)$ & 0.31 & 0.41 & 0.03 & 0.29 & 0.95 & 0.97 & $\mathbf{0 . 5 4}$ & 0.39 \\
Ride ability & $(8)$ & 0.62 & 0.86 & 0.58 & 0.81 & 0.21 & 0.27 & 0.26 & $\mathbf{0 . 1 4}$ \\
\hline
\end{tabular}

Table 3

Coefficients of heritability, genetic, phenotypic and residual correlation coefficients, between scores of trainers and judges. (Heritabilitätskoeffizienten, genetische, phänotypische und residuale Korrelationskoeffizienten, zwischen Noten der Trainer und Richter.)

\begin{tabular}{|c|c|c|c|c|c|}
\hline \multirow{2}{*}{ Trait } & \multicolumn{2}{|c|}{ Heritability } & \multirow{2}{*}{$\begin{array}{l}\text { Phenotypic } \\
\text { correlation }\end{array}$} & \multirow{2}{*}{$\begin{array}{c}\text { Genetic } \\
\text { correlation }\end{array}$} & \multirow{2}{*}{$\begin{array}{c}\text { Residual } \\
\text { correlation }\end{array}$} \\
\hline & Trainer & Judges & & & \\
\hline Trot & 0.32 & 0.25 & 0.62 & 0.94 & 0.50 \\
\hline Canter & 0.42 & 0.24 & 0.58 & 0.99 & 0.41 \\
\hline Walk & 0.32 & 0.21 & 0.57 & 0.94 & 0.44 \\
\hline Basic gaits & 0.39 & 0.24 & 0.66 & 0.99 & 0.50 \\
\hline Manner & 0.44 & 0.29 & 0.53 & 0.95 & 0.30 \\
\hline Ability & 0.58 & 0.38 & 0.57 & 0.92 & 0.26 \\
\hline Free jumping & 0.57 & 0.35 & 0.58 & 0.93 & 0.31 \\
\hline Ride ability & 0.19 & $0.07 *$ & $0.43^{*}$ & $0.84 *$ & $0.38 *$ \\
\hline
\end{tabular}

- connected with foreign rider

The estimated heritabilities of trainer's scores are always higher than those of judges (Table 3). Especially striking is the very low value for ride ability. Also for the score 
of the foreign rider, a very low value was estimated (0.07). The phenotypic and residual correlation coefficients between both trainers and judges are mainly in a middle level. On the other hand the genetic coefficients are close to one. The foreign rider scores (not shown) correlate with the trainer's scores by $0.84,0.43$ and 0.38 for the genetic, phenotypic and residual coefficients, respectively. The corresponding correlation coefficients for the judges' scores are $0.88,0.53$ and 0.50 . All coefficients are estimated with error standard deviations in the range of 0.01 to 0.05 .

\section{Discussion}

The mare performance test is implemented both as a station test and as a field test (BUGISLAUS et al., 2004; KOENEN, 2002). On station mares are trained over 14 days, but the field test is an one day event. Mares on station are evaluated by trainer, foreign riders and judges, the judgment of mares in the field is exclusively carried out by judges and foreign riders. Therefore both tests are not fully comparable and could lead to different parameters. However, BÖSCH et al. (2000) cite studies of CHRISTMANN (1996) who have found only slight genetic difference between station and field. Because of the consistency of the training it can be expected, that the heritability coefficients are higher for the station test. The results of WILLMS et al. (1999), who estimated heritability coefficients between 0.29 and 0.85 for the same traits as studied here, can be taken as a confirmation of this expectation. For the same reasons, differences in phenotypic correlation coefficients are also possible between station and field. That is in agreement with BÖSCH et al. (2000), who estimated distinctly closer correlations than WILLMS et al. (1999). The heritabilities and genetic correlations for the trait gaits (Table 2) correspond with estimates from other studies. BÖSCH et al. (2000), LUEHRS-BEHNKE et al. (2002) and CHRISTMANN (2003) report estimates from 0.26 to 0.38 for heritability and in from 0.27 to 0.82 for genetic correlations. BÖSCH et al. (2000) merged field and station data and found higher phenotypic correlations ( $0.91,0.84,0.86$ for $1: 2,1: 3$; $2: 3$, respectively). In the present study, the free jumping traits are very hereditary and closely genetically and phenotypically correlated. It is think-worth to specify free jumping by the trait ability alone. That would increase the heritability from 0.54 up to 0.58 . The heritability of ride ability is very modest. This value does not agree with the mostly mentioned results of the literature which are in the range of 0.3, as reported by BROCKMANN and BRUNS (2000), BRUNS and SCHADE (2000), BÖSCH et al. (2000), LUEHRSBEHNKE et al. (2002) and CHRISTMANN (2003) who merged data from field and station. On the other hand, KÜHL et al. (1994), using station data, estimated heritabilities in the region of 0.14 to 0.22 . Perhaps, the low heritabilities could be caused by differences in the definition of the trait, with a preference more for basic gaits (DIETL et al., 2004). In this study, the phenotypic and genetic correlations suggest an emphasis on gaits (Table 2). WILLMS et al. (1999) estimated heritabilities separately for trainer, judges and foreign riders using 1240 station records. The heritabilities concerning trainer's scores were $0.56,0.50,0.58,0.33$ and 0.69 for trot, canter, walk, ride ability and free jumping, respectively. Heritabilities involving judge's scores were 0.29 for ride ability and 0.85 for free jumping. The corresponding value for ride ability based on foreign rider's scores was 0.30 . However, their results are explicitly higher than those of this study (Table 3) and also higher as KÜHL et al. (1994) reported. This could have been caused by the additional consideration of the 
factor 'trainings group'. All over all, heritabilities concerning trainer are distinctly higher than the others. The possible cause of that higher heredity could be related to the longer time of evaluation by the trainer. SCHWARK et al. (1992) examined the influence of the rider in the station own-performance test of males and found great differences. Judges have not more than 10 minutes for their evaluation, and therefore, the results will be strongly influenced by the instantaneous form of the mare. This concept is supported by the quite low residual correlations (Table 3) indicating rather small environmental relationships between both kinds of scores. That seems to be also applicable to the relationship of trainer and foreign rider for ride ability. The trends of evaluations are different between trainer and judges with respect to some fixed factors. For instance, see Figure 2.
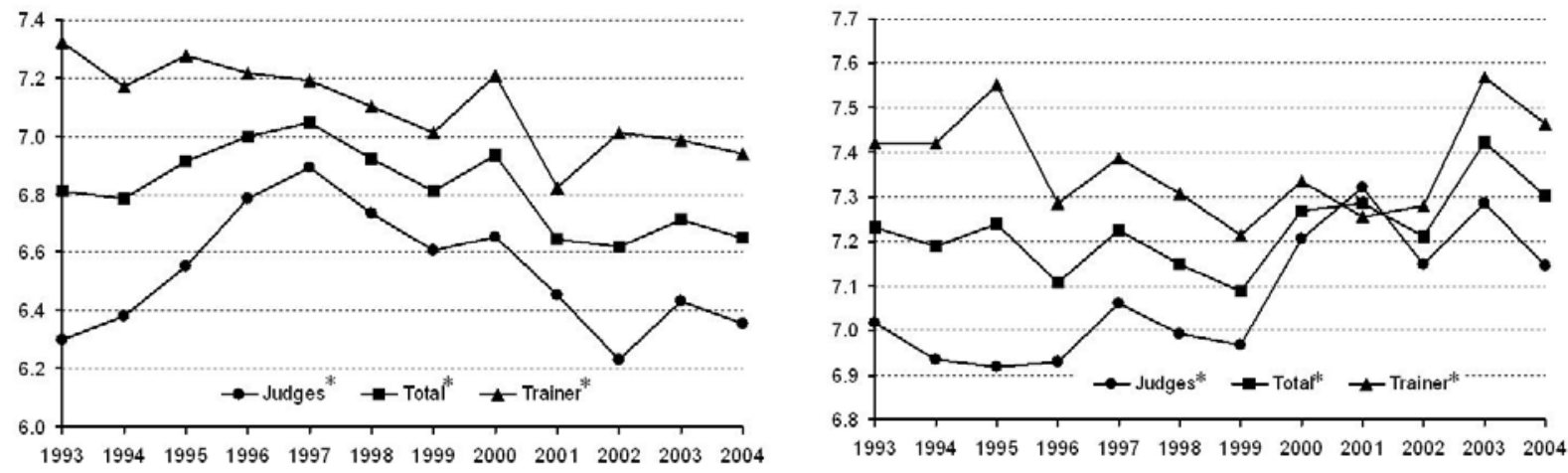

Fig. 2: Effects of years in the traits trot (left) and free jumping (right) (Effekte der Jahre in den Merkmalen Trab (links) und Freispringen (rechts))

* Effects significant different from their mean value; $\mathrm{p}<0.05$

Table 4

Optimal weights, maximum of $\mathrm{h}^{2}$, loss by use of weights $0.5: 0.5$ and partial coefficients of determination. (Optimale Gewichte, maximales $h^{2}$, Verlust bei Gewichtung 0.5:0.5, partielle Bestimmtheiten.)

\begin{tabular}{lcccccc}
\hline \multirow{2}{*}{ Trait } & \multicolumn{2}{c}{ Optimal weights } & $\begin{array}{c}\text { Maximum of } \\
\mathrm{h}^{2}\end{array}$ & $\begin{array}{c}\text { Loss [\%] by } \\
0.5: 0.5\end{array}$ & \multicolumn{2}{c}{$\begin{array}{c}\text { Partial coefficients of } \\
\text { determination [\%] }\end{array}$} \\
& Trainer & Judges & & & Trainer & Judges \\
\hline Trot & 0.663 & 0.337 & 0.35 & 2.2 & 13.5 & 5.2 \\
Canter & 0.796 & 0.204 & 0.43 & 8.8 & 26.2 & 2.9 \\
Walk & 0.733 & 0.267 & 0.34 & 5.3 & 17.0 & 3.7 \\
Basic gaits & 0.772 & 0.228 & 0.40 & 6.6 & 21.2 & 1.8 \\
Manner & 0.748 & 0.252 & 0.48 & 7.4 & 27.4 & 8.2 \\
Ability & 0.741 & 0.259 & 0.61 & 5.5 & 37.6 & 11.1 \\
Free jumping & 0.805 & 0.195 & 0.59 & 8.9 & 37.4 & 7.7 \\
Ride ability & 0.934 & $0.066^{*}$ & $0.19 *$ & $26.2 *$ & 13.3 & $0.58^{*}$ \\
\hline - connected with foreign rider & & & & & &
\end{tabular}

The trait 'trot' shows a parallel course between trainers and judges over years indicating a constant evaluation base of both sides. In contrast, the same trends of the trait ' free jumping' present a clear discrepancy in the year 2001. In general, the trends proceed parallel with respect to basic gaits while differences are found more frequently in the ride ability and free jumping. Possibly the reasons could be suspected in changes of the team compositions. The genetic correlations between trainers and their 
counterparts are close to 1 with exception of ride ability. Advantageously, both parties evaluate the same genetic characteristics of the mares. However, these close correlations should not be an instigation to terminate the evaluation by one of both sides. But here the information content is also important which appears in the correlation coefficients and particularly in the heritability. For more insight, the problem can be transformed into the task to determine a linear function that has a maximum heritability coefficient (Table 4). The current weights of 0.5 to 0.5 is not optimal. The scores of the trainers should be taken into account stronger, approximately in the relationship of 0.75 to 0.25 . However, the increase in heredity is not very serious with approximately 5 percent. Regarding the ride ability, an even stronger emphasis of the trainer's scores seems to be necessary, approximately in the relation 0.9 to 0.1 . Then the relative increase is the largest. The shape of the function can be seen in the Figure 3.
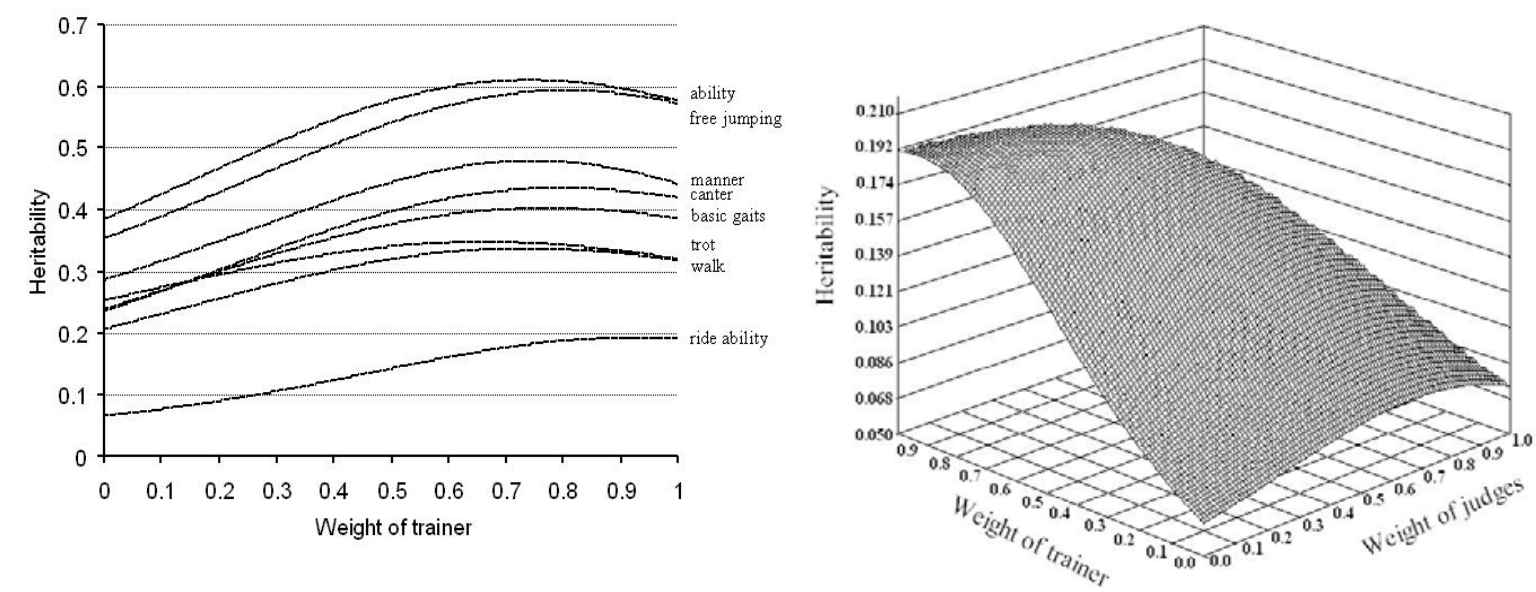

Fig. 3: Heritability coefficients in dependence on the weights for trainers and judges (Ride ability; right) . (Heritabilitätskoeffizienten in Abhängigkeit der Gewichte für Trainer und Richter (Rittigkeit, rechts))

By the way, an additional consideration of the judges scores changes this relation only insignificantly (Figure 3, right). The partial coefficients of determinations quantify the influence of the both types of scores on the breeding value of the total trait in the case of optimum. Therefore, they confirm the clearly larger impact of the trainer's judgments.

\section{Conclusions and recommendations}

The genetic and phenotypic parameters of Mecklenburger Warmbood Horses are similar to those from the literature, with exception of the trait ride ability. The heredity of this trait is very low and it should be pursued the causes. The impacts of the trainer's scores on the breeding values are clearly higher than those from judges. The currently used weights for the trainer's scores and judges' scores can be optimized by putting more weight on the trainer's scores.

\section{Acknowledgements}

The authors thank the Association of Horse Breeders of Mecklenburg-Western Pomerania for providing the data. Furthermore, we thank Dr. Armin Tuchscherer and Dr. Volker Guiard for their support. 


\section{References}

BÖSCH, M., REINECKE, S., KALM, E.:

Genetische Analyse von Merkmalen in der Reitpferdezucht - Varianzkomponenten für Merkmale der Fohlenbeurteilung, Stutbuchaufnahme (Exterieurbeurteilung) und Zuchtstutenprüfung. Züchtungskunde 72 (2000), 161-171

BROCKMANN, A., BRUNS, E.:

Schätzung genetischer Parameter für Merkmale aus Leistungsprüfungen für Pferde. Züchtungskunde $\mathbf{7 2}$ (2000), 4-16

BRUNS, E., SCHADE, W.:

Genetic value of various performance test schemes of young riding horses. $6^{\text {th }}$ WCGALP, 24 (2000), $420-423$

BUGISLAUS, A.-E.; ROEHE, R.; UPHAUS, H.; KALM, E.:

Development of genetic models for estimation of racing performances in German thoroughbreds. Arch. Tierz., Dummerstorf 47 (2004) 6, 505-516

CHRISTMANN, L.:

Zuchtwertschätzung für Merkmale der Stutbuchaufnahme und der Stutenleistungsprüfung im Zuchtgebiet Hannover. Diss. Göttingen. (1996)

CHRISTMANN, L.:

Specialists or All-rounders? Degrees of heritability and genetic correlations in the Hanoverian breed. http://www.hanoverian.com/ludwigherit.html, (2003)

DIETL, G.; HOFFMANN, S.; ALBRECHT, S.:

Parameter und Trends der Stutbuchaufnahme des Mecklenburger Warmblut Pferdes. Arch. Tierz., Dummerstorf 47 (2004) 2, 107-117

GROENEVELD, E.; KOVAC, M.:

A Generalised Computing Procedure for Setting up and Solving Mixed Linear Models. J. Dairy Sci., Champaign, III. 73 (1990), 513-531

GROENEVELD, E.:

VCE4 User's Guide and Reference Manual, Version 4.2.5, Inst. of Anim. Husbandry and Anim. Sci., Mariensee, Germany, (1998)

KOENEN, E.C.P.:

Prüfungsverfahren und Zuchtwertschätzung für Sportpferde im internationalen Vergleich. Arch. Tierz., Dummerstorf 45 (2002) Sonderheft, 38-44

KÜHL, K., PREISINGER, R., KALM, E.:

Analyse von Leistungsprüfungen und Entwicklung eines Gesamtzuchtwertes für die Reitpferdezucht. 1. Mitteilung: Analyse der Exterieurbeurteilung und Leistungsprüfungen. Züchtungskunde 66 (1994), 1-13

LÜHRS-BEHNKE, H., ROEHE, R., KALM, E.:

Genetic associations among traits of the new integrated breeding evaluation method used for selection of German Warmblood Horses. Veterinarija ir Zootechnika. T. 18 (2002), 90-93

ROEHE, R.; SAVAS, T.; BRKA, M.; WILLMS, F.; KALM, E.:

Multiple-trait genetic analyses of racing performances of German trotters with disentanglement of genetics and driver effects. Arch. Tierz., Dummerstorf 44 (2002) 6, 579-587

SCHWARK, H.J.; PETZOLD, P.; KARWATH, M.:

Untersuchungen zur Objektivität und zur züchterischen Effektivität der stationären Eigenleistungsprüfungen von Hengsten der Reitpferderassen. Arch. Tierz., Dummerstorf 35 (1992) 1/2, 97-106

WILLMS, F., RÖHE, R., KALM, E.:

Genetische Analyse von Merkmalskomplexen in der Reitpferdezucht unter Berücksichtigung von Gliedmaßenveränderungen. 2. Mitteilung: Genetische Beziehungen zwischen Merkmalen aus der Stutbucheintragung, Stutenleistungsprüfung und Gliedmaßenveränderungen. Züchtungskunde $\mathbf{7 1}$ (1999), 346-358

Received: 2005-01-11

Accepted: 2005-03-02

Corresponding author

Dr. GERHARD DIETL

Forschungsinstitut für die Biologie landwirtschaftlicher Nutztiere (FBN)

Forschungsbereich Genetik und Biometrie

Wilhelm-Stahl-Allee 2

18196 DUMMERSTORF / GERMANY

E-mail: dietl@fbn-dummerstorf.de 